PERBEDAAN DASAR KONSEP UPAH ISLAM DAN BARAT

Oleh

Husnul Khotimah', Iramasan Efendi ${ }^{2}$

1,2Universitas Darussalam (UNIDA) Gontor

Email: 1husnulkhotimah42013@mhs.unida.gontor.ac.id,

2iramasanefendi@gmail.com ${ }^{2}$

Article History:

Received: 05-10-2021

Revised: 15-11-2021

Accepted: 23-11-2021

Keywords:

Perbedaan, Konsep Upah Islam

\begin{abstract}
Islam memiliki peinsip dasar dalam kegiatan ekonomi (mu'amalah) secara umum, trutama prinsip keadilan (al-'adl) dan perinsip moralitas (al-akhlak). Dalam konteks hukum ekonomi tidak hanya bernilai yuridis ekonomi semata, tetapi juga berdimensi teologis. Keadilan dalam Islam adalah keadilan ilahi, yaitu keadan yang tidak terpisah dari moralitas, didasarikan pada nilai-nilai absolut yang diwahyukan Tuhan dan penerimaan manusia terhadap nilai-nilai tersebut merupakan suatu kewajiban. perbeadan dasar antara konsep upah dalam Islam dan Barat. Menurut Islam uapah adalah imbalan yang diterima seseorang atas pekerjaannya dalam benruk imbalan materi di dunia yaitu (adil dan layak) dalam bentuk imbalan pahala di akhirat (imbalan yang lebih baik). Islam melihat upah sangat besar kaitannya dengan konsep moral. Upah dalam Islam tidak hanya materi (kebenadaan atau keduniaan) tetapi menembus batas kehidupan, yakni berdimensi akherat yang disebut dengan pahala. Sedangkan Barat menganggap bahwa upah atau gaji biasa, pokok atau minimum yang dibayarka secara langsung baik dalam bentuk uang tunai atau barang, oleh pengusaha kepada pekerja dalam kaitan dengan hubungan kerja.
\end{abstract}

\title{
PENDAHULUAN
}

Pada zaman perindustrian sekitar abad 18 yang dimulai dengan zaman kebangunan ialah zaman dimana kebutuhan akan tenaga manusia sebagai pemacu pertumbuhan produksi. Kepemanfaatan tenaga manusia identik dengan kerja dan upah yang diberikan oleh perusahaan. Dengan bertambahnya kebutuhan hidup pekerja dan keluarga yang harus dipenuhi. Dampak dari hal tersebuat ialah persoalan upah terhadap tenaga kerja manusia. Sampai saat ini belum ditemukan solusi kebijakan pemerintah terkait dengan penetapan besaran kecilnya upah yang terkadang lebih memihak kepada kepentingan para 
JCI

Jurnal Cakrawala Ilmiah

Vol.1, No.3, November 2021

pengusaha. ${ }^{1}$

Badan Pusat Statistik (BPS) mencatat, jumlah pengangguran di Indonesia mencapai 8,75 juta orang pada Februari 2021. Jumlah tersebut meningkat 26,26\% dibandingkan periode yang sama tahun lalu sebesar 6,93 juta orang. Hari buruh dunia yang bertepatan dengan tanggal 1 Mei yang dijadikan sebagai momentum dalam rangka memperjuangkan kesejahteran memlalui aksi unjuk rasa secara masal baik dengan mogok kerja ataupun erorasi dengan meninggalkan tugas pokok yang seharusnya ditunaikan. Adanya aksi ini sebagai bentuk protes atar berbagai kebijakan pemerintah maupun perusahaan yang tidak berpihak dan bahkan merugikan pekerja, terutama yang berkaitan dengan upah. Cara tersebut dianggap efektih untuk memperjuangkan tuntutan, sebab bisa memberikan tekanan kepada pemerintah dan pihak manajemen perusahaan untuk memmenuhi tuntutan mereka. ${ }^{2}$

Islam memiliki peinsip dasar dalam kegiatan ekonomi (mu'amalah) secara umum, trutama prinsip keadilan ( $\left.a l^{\prime}{ }^{\prime} a d l\right)$ dan perinsip moralitas (al-akhlak). Dalam konteks hukum ekonomi tidak hanya bernilai yuridis ekonomi semata, tetapi juga berdimensi teologis. Keadilan dalam Islam adalah keadilan ilahi, yaitu keadan yang tidak terpisah dari moralitas, didasarikan pada nilai-nilai absolut yang diwahyukan Tuhan dan penerimaan manusia terhadap nilai-nilai tersebut merupakan suatu kewajiban. Semuai itu akan berimplikasi bahwa seluruh hukum ekonomi yang diterapkan harus sejalan dengan nilai-nilai moral yang bersumber dari al-Qur'an dan al-Hadits ${ }^{3}$

Manusia sebagai khalifatullah di bumi harus memelihara hukum dan menjamin bahwa pemakaian segala sumber daya diarahkan untuk kesejahteraan manusia agar semua mendapat manfaat secara adil dan baik. Nilai keadilan itu harus diterapkan secara menyeluruh dalam bidang kehidupan, termasuk bidang ekonomi. Kosep khilafah meyiratkan kesatuan fundamental dan persaudaraan umat manisia, dimana setiap manusia memiliki hak istimewa. Hal ini menumbuhkan kesadaran sosial dan martabat semua manusia dan menjadi elemen utama dari iman Islam. Salah satu gaya hidup yang sesuai dengan khalifah Allah adalah gaya hidup yang rendah hati dan tidak merugikan kemampuan masyarakat dalam memenuhi kebutuhannya. ${ }^{4}$

Namun, kenyataan yang terjadi di Indonesia saat ini adalah belum adanya khalifah yang benar-benar mampu menyelesaikan permasalahan perekonomi Indonesia. Dimana masih banyak dari penduduk yang depresi, warga yang bunuh diri dengan alasan tidak tahan menanggung beban ekonomi. Sementara demo juga semakin sering terjadi, Ini menunjukkan ketidakpuasan akan kondisi ekonomi yang dirasakan masyarakat.

\section{Rumusan Masalah}

Tujuan penelitian ini ialah, untuk mengetahi bagaimana agama Islam berbicara dan membahas ketentuan-ketentuan tentang upah yang bersumber dari al-Qur'an dan Hadits. Dengan mengikuti perkembangan zaman ini, manusia semakin berlomba-lomba untuk

${ }^{1}$ Armansyah Waliam, 'Upah Berkeadilan Ditinjau Dari Perspektif Islam', Jurnal STIE Bank BPD Jateng, Vol. 5.No. 2 (2017), 292 (pp. 265-67).

${ }^{2}$ Baitus Salamah and Imahda Khoiri Furqon, 'Pengaruh Pandemi Covid Terhadap Penerimaan Pajak Di Negara Indonesia Pada Tahun 2020', Jurnal Akuntansi, Perpajakan Dan Auditing, 1.2 (2020).

${ }^{3}$ M. UMER CHAPRA and The, Islam and The Economic Challenge (Kano. Nigeria British: The Islamic Foundation and The International Institute of Islamic Thought, 1992), p. 209.

${ }^{4}$ CHAPRA and The, pp. 202-8. 
meningkatkan berbagai inovasi dengan menciptakan trobosan baru untuk mendukung semua aktifitas manusia. Berdasarkan uraian di atas kita juga dapat menarik beberapa rumusan masalah salah satunya ialah: Apa perbedaan dasar konsep upah dalam Islam dan Barat? Bagaimna agar penentuan upah dapat dikakan adil dan layak?

\section{METODE PENELITIAN}

Untuk mengkaji penelitian ini maka digunakan metode kualitatif dengan melakukan pendekatan metode studi dengan trmuan konsep baru, yang bertujuan untuk menghasilkan temuan yang benar-benar bermanfaat sehingga memerlukan perhatian serius terhadap berbagai hal yang dipandang perlu. Segala informasi tentang upah dalam al-Quran, Hadits dan pendapat ulama' diuraikan dan didisiplinkan secara tematis, dan komprehensf. ${ }^{5}$ Setelah semua data terkumpul kemudian data akan dianalisi dengan beberapa cara, diantaranya yaitu Interprestasi, adalah upaya tercapainya pemahaman yang benar terhadap fakta, data dan gejala. Setelah data semua terkumpulan dan telah dilakukan metode analisis maka dapat dijelaskan secara umum bagaimana hendaknya penelitian ini disusun secara disiplin agar isinya dapat dipahami secara runtut dan analistis. ${ }^{6}$

\section{Pembahasan}

\section{Pengertian Upah (Ijarah)}

Upah dalam Islam dikenal dengan istilah ijarah. Hanafiyah mengatakan bahwa ijarah adalah akad atas manfaat disertai imbalan. ${ }^{7}$ Ijarah adalah pemilik jasa dari orang yang menyewakan (mu'ajjir) oleh orang yang menyewa (musta'jir), serta pemilikan harta dari pihak musta'jir oleh seorang mu'ajjir. Dengan demikian, ijarah berarti merupakan transaksi terhadap jasa tertentu, dengan disertai kompensasi tertentu pula. Jumhur ulama juga berpendapat bahwa ijrah disyaratkan berdasarkan Al-Qur'an dan Hadits. Dan ini diterangkan dalam Al-Qur'an yang artinya:

"Salah seorang dari kedua wanita itu berkata: "Ya bapakku ambillah ia sebagai orang yang bekerja (pada kita), karena sesungguhnya orang yang paling baik yang kamu ambil untuk bekerja (pada kita) ialah orang yang kuat dan dapat dipercaya". Berkatalah dia (Syu'ab): "Sesungguhnya aku bermaksud menikahkan kamu dengan salah seorang dari kedua anakku ini, atas dasar bahwa kamu bekerja denganku delapan tahun dan jika kamu cukupkan sepuluh tahun maka itu adalah (suatu kebaikan) dari kamu, maka aku tidak hendak memberhentikan kamu. Dan kamu Insya Allah akan mendapatiku termasuk orangorang yang baik". (Al-Qashash: 26: 27)

Dan dalam Hadits yang berbunyi:

$$
\text { اعطوا الاجبر اجره قبل ان يجف عرقه }
$$

Artinya: Berikanlah upah bekerja sebelum keringatnya kering. (HR. Ibn Majah dari Ibn Umar).

Konsep awal ijarah adalah akad sewa sebagaimana yang telah terjadi pada umumnya. Hal yang harus diperhatikan adalah behwa pembayaran oleh penyewa merupakan timbal balik dari manfaat yang telah ia nikmati. Objek dalam akad ijarah adalah

${ }^{5}$ M.Ag Prof. Dr. H Boedi Abdullah and M.Si Drs. Beni Ahmad Saebani, Metode Penelitian Ekonomi Islam Muamalah (CV Pustaka Setia, 2014), p. 49.

${ }^{6}$ Annisa Silvi Kusumastuti, 'Menurut Ibnu Miskawaih', 07.April (2020), 250-72 (p. 255).

${ }^{7}$ Sayyid Sabiq, Fikih Sunnah 13 (Bandung: PT Alma’arif, 1987), p. 15. 
JCI

\section{Jurnal Cakrawala Ilmiah}

manfaat itu sendiri, bukan bendanya. Karena dalam objek ijarah tidak selamanya manfaat diperoleh dari sebuah benda, akan tetapi bisa juga berasal dari tenaga manusia. Ijarah yang dimaksud dalam pengertian ini ialah upah-mengupah dalam masyarakat. ${ }^{8}$

Upah atau gaji merupakan pembayaran yang diberikan oleh majikan kepada pekerja atas usahanya terlibad dalam proses produksi. Upah dapat dinisbatkan pada penghasilan yang diperoleh tenaga kerja yang dalam hal ini dapat dipandang sebagai jumlah uang yang diperoleh dari seseorang pekerja selama jangka waktu yang sudah ditentukan. Besar kecil upah atau gaji tersebut ditentukan oleh jumlah atau jenis pekerjaannya. Upah atau gaji pokok atau minimum dan setiap tambahan yang dibayar langsung atau tidak langsung dapat dalam bentuk uang tunai atau barang oleh pengusaha kepada pekerja dalam kaitan hubungan kerja. Sistem pemberian balas jasa yang baik adalah mudah dihitung, mudah dimengerti, motivasi efektif, adanya hubungan antara kerja dan upah serta satabil. Dan besar maupun kecil imbalan harus sebanding dengan harga nyata pekerjaannya, bukan harga nominal atas jerih payahnya. ${ }^{9}$

Menurut Mannan, upah merupakan imbalan yang diterima oleh para pekerja. Imbalan yang dimaksudkan sebagai upah dapat dilihat dari dua sisi sudut pandang yaitu dari sudut pandang moneter dan bukan moneter, dalam artian upah dilihat daribeberapa banyak uanga yang diterima pekerja dalam masa waktu tertentu, serta kuantitas hidup para pekerja yang ia dapat karena bekerja. Upah secara garis besar dapat dikategorikan atas pemberian imbalan karena mengambil manfaat dari suatu barang, seperti rumah, pakaian dan lain-lain. Atau pemberian imbalan akibat suatu pekerjaan yang dilakukan oleh seseorang, seprti seorang pelayan jenis pertama mengarah kepada sewa menyewa dan yang kedua lebih menuju kepada ketenagakerjaan. ${ }^{10}$

\section{Perbedaan Konsep Upah Islam dan Barat}

Filsafah Islam dalam pemberian upah adalah adil dan kompetitif, maksud dari adil disini menjelaskan bahwa sesuatu adalah objektif, sedangkan kompetitif menggambarkan bahwa tidak kalah dengan sistem imbalan dalam organisasi sejenis. Menurut Yusuf Qardhawi, faktor internal dalam kebijakan imbalan antara lain: kemampuan perusahaan untuk membayar, kerakteristik pekerjaan dan karakteristik pekerja. Sedangkan faktor ekternalnya antara lain: keadaan pasar, tenaga kerja, standar biaya hidup, tingkat upah industry sejenis dan peraturan pemerintah mengenai imbalan.

Allah menegaskan tentang imbalan dalam Qur'an yang artinya:

"Dan katakanlah: "Bekerjalah kamu, maka Allah dan Rasul-Nya serta orang-orang mu'min akan melihat pekerjaanmu itu, dan kamu akan dikembalikan kepada Allah Yang mengetahui akan ghaib dan yang nyata, lalu diberikan-Nya kepada kamu apa yang kamu kerjakan" (At-Taubah: 105).

"Sesungguhnya mereka yang beriman dan beramal saleh tentulah Kami tidak akan menyia-nyiakan pahala orang-orang yang megerjakan amalannya dengan baik." (Al-Kahfi: 30).

Menurut Dewan Penelitian Perubahan Nasional, upah adalah suatu penerimaan

8 M. Yazid Affandi, Fiqih Muamalah Dam Implementasinya Dalam Lembaga Keuangan Syari'ah (Yogyakarata: Logung Pustaka, 2012), p. 180.

${ }^{9}$ Ruslan Abdul Ghofur, ‘Konsep Upah Dalam Ekonomi Islam’ (Arjasa Pratama, 2020), pp. 8-9.

${ }^{10}$ Wahbah al-Zuhayli, Al-Fiqh Al-Islam Iy Wa Adillatuhu, Juz IV, p. 3811. 
sebagai imbalan dari pemberi kepada penerima kerja untuk suatu pekerjaan atau jasa yang telah dan akan silakukan, berfungsi sebagai jaminan kelangsungan hidup yang layak bagi kemanusiaan dan produk, dinyatakan atau dinilai dalam bentuk uang yang ditetapkan menurut suatu persetujuan, undang-undang dan peraturan dan dibayarkan atas dasar suatu perjanjian kerja antara pemberi dan penerima kerja. ${ }^{11}$

Pada saat pegawai bergabung dengan suatu organisasi, mereka membuat perjanjian ekonomis dan psikologis yang tidak tertulis, meskipun pada umumnya mereka melakukannya secara tidak sadar. Perjanjian psikologis, menetapkan syarat keterlibatan psikologis masing-masing pegawai dengan sistem, dan menuntut lebih dari sekedar imbalan ekonomis, mereka berusaha untuk mendapatkan rasa aman, perlakuan sebagai manusia, hubungan yang baik dengan orang lain, dan dukungan untuk memenuhi harapan. Jika organisasi hanya mementingkan perjanjian ekonomis, kepuasan kerja dan prestasi pegawai akan cenderung menurun. ${ }^{12}$

Sebaliknya jika harapan psikologis dan ekonomis mereka terpenuhi, pegawai cenderung merasa puas dan berusaha untuk berprestasi. Upah menurut pengertian Barat terkait dengan pemberian imbalan kepada pekerja tidak tetap, atau tenaga buruh lepas, seperti upah buruh lepas di perkebunan kelapa sawit, upah pekerja bangunan yang dibayar mingguan atau bahkan harian. Sedangkan gaji menurut pengertian Barat terkait dengan imbalan uang (finansial) yang diterima oleh karyawan atau pekerja tetap dan dibayarkan sebulan sekali. Sehingga dalam pengertian barat, Perbedaan gaji dan upah itu terletak pada Jenis karyawannya (Tetap atau tidak tetap) dan sistem pembayarannya (bulanan atau tidak). Meskipun titik berat antara upah dan gaji terletak pada jenis karyawannya apakah tetap ataukah tidak. ${ }^{13}$

Dalam hal perbedaan pengertian upah dan gaji menurut konsep Barat di atas, maka Islam menggariskan upah dan gaji lebih komprehensif dari pada Barat. Allah menegaskan tentang imbalan ini dalam menafsirkan At Taubah ayat 105 ini, Quraish Shihab menjelaskan dalam kitabnya Tafsir Al-Misbah sbb :

"Bekerjalah Kamu, demi karena Allah semata dengan aneka amal yang saleh dan bermanfaat, baik untuk diri kamu maupun untuk masyarakat umum, maka Allah akan melihat yakni menilai dan memberi ganjaran amal kamu itu"

Berdasarkan surat diatas suatu organisasi harus berkewajiban menilai dan memberi ganjaran terhadap amal-amal itu. Dengan kata lain daripada ganjaran adalah imbalan atau upah atau compensation. Sementara menurut Syeikh Az- Zamakhsari, Amal Saleh adalah segala perbuatan yang sesuai dengan dalil akal, al-Qur'an dan atau Sunnah Nabi Muhammad Saw. Berdasarkan tiga ayat diatas, yaitu At- Taubah 105, An-Nahl 97 dan Al-Kahfi 30, maka Imbalan dalam konsep Islam menekankan pada dua aspek, yaitu dunia dan akherat. Tetapi

${ }^{11}$ Dina Mellita Wiwin Agustian, 'KONSEP PENGUPAHAN DALAM MANAJEMEN SYARIAH', JIBM, Vol. 3.No. $\quad 11020), \quad$ (2020) <https://journal.binadarma.ac.id/index.php/BINAMANAJEMEN/article/view/827/469> [accessed 7 October 2021].

12 Mastura Nurmala Sari, Safwan Kamal, Junaidi, 'KELAYAKAN DAN KEADILAN DALAM PENETAPAN UPAH NELAYAN KAPAL PUKAT LANGGAR KUALA LANGSA DITINJAU DARI PERSPEKTIF ETIKA BISNIS ISLAM', J-EBIS (Jurnal Ekonomi Dan Bisnis Islam), Vol. 6.No. 1 (2021), 54 <https://doi.org/10.32505/j-ebis.v6i1.2624>.

13 Yulianti Yulianti, Salmaini Yelly, and Khotimah, 'MENJADI WANITA KARIR Persepsi Karyawan Muslin Dan Kristen Di Pekanbaru', TOLERANSI: Media Ilmiah Komunikasi Umat Beragama, Vol, 12.No. 2 (2021), $175<$ https://doi.org/10.24014/trs.v12i2.13546>. 
JCI

Jurnal Cakrawala Ilmiah

Vol.1, No.3, November 2021

hal yang paling penting, adalah bahwa penekanan kepada akherat itu lebih penting daripada penekanan terhadap dunia (dalam hal ini materi) sebagaimana semangat dan jiwa Al-Qur'an surat Al-Qhashsash ayat 77.14

Sementara menurut Syeikh Az- Zamakhsari, Amal Saleh adalah segala perbuatan yang sesuai dengan dalil akal, al-Qur'an dan atau Sunnah Nabi Muhammad Saw. Berdasarkan tiga ayat diatas, yaitu At- Taubah 105, An-Nahl 97 dan Al-Kahfi 30, maka Imbalan dalam konsep Islam menekankan pada dua aspek, yaitu dunia dan akherat. Tetapi hal yang paling penting, adalah bahwa penekanan kepada akherat itu lebih penting daripada penekanan terhadap dunia (dalam hal ini materi) sebagaimana semangat dan jiwa Al-Qur'an surat Al-Qhashsash ayat 77.

Surat At-Taubah 105 menjelaskan bahwa Allah memerintahkan kita untuk bekerja, dan Allah pasti membalas semua apa yang telah kita kerjakan. Yang paling unik dalam ayat ini adalah penegasan Allah bahwa motivasi atau niat bekerja itu mestilah benar. Sebab kalau motivasi bekerja tidak benar, Allah akan membalas dengan cara memberi azab. Sebaliknya, kalau motivasi itu benar, maka Allah akan membalas pekerjaan itu dengan balasan yang lebih baik dari apa yang kita kerjakan (An-Nahl: 97). ${ }^{15}$

Lebih jauh Surat An-Nahl: 97 menjelaskan bahwa tidak ada perbedaan gender dalam menerima upah / balasan dari Allah. Ayat ini menegaskan bahwa tidak ada diskriminasi upah dalam Islam, jika mereka mengerjakan pekerjaan yang sama. Hal yang menarik dari ayat ini, adalah balasan Allah langsung di dunia (kehidupan yang baik/rezeki yang halal) dan balasan di akherat (dalam bentuk pahala). Sementara itu, Surat Al-Kahfi: 30 menegaskan bahwa balasan terhadap pekerjaan yang telah dilakukan manusia, pasti Allah balas dengan adil. Allah tidak akan berlaku zalim dengan cara menyia- nyiakan amal hamba-Nya. Konsep keadilan dalam upah inilah yang sangat mendominasi dalam setiap praktek yang pernah terjadi di negeri Islam.Lebih kalau kita lihat hadits Rasulullah saw tentang upah yang diriwayatkan oleh Abu Dzar bahwa Rasulullah s.a.w bersabda: ${ }^{16}$

"Mereka (para budak dan pelayanmu) adalah saudaramu, Allah menempatkan mereka di bawah asuhanmu; sehingga barang siapa mempunyai saudara di bawah asuhannya maka harus diberinya makan seperti apa yang dimakannya (sendiri) dan memberi pakaian seperti apa yang dipakainya (sendiri); dan tidak membebankan pada mereka dengan tugas yang sangat berat, dan jika kamu membebankannya dengan tugas seperti itu, maka hendaklah membantu mereka (mengerjakannya)." (HR. Muslim).

Dari hadits ini dapat didefenisikan bahwa upah yang sifatnya materi (upah di dunia) mestilah terkait dengan keterjaminan dan ketercukupan pangan dan sandang. Perkataan: "harus diberinya makan seperti apa yang dimakannya (sendiri) dan memberi pakaian seperti apa yang dipakainya (sendiri)", bermakna bahwa upah yang diterima harus menjamin makan dan pakaian karyawan yang menerima upah. Sehingga dari ayat-ayat Al-Qur'an di atas, dan dari hadits-hadits di atas, maka dapat didefenisikan bahwa: Upah adalah imbalan

\footnotetext{
${ }^{14}$ Fauzi Caniago, 'Ketentuan Pembayaran Upah Dalam Islam', Jurnal Textura, Vol. 1.No. 5 (2018), 48.

${ }^{15}$ Hendy Herijanto Muhammad Nurul Hafiz, 'Pengupahan Perspektif Ekonomi Islam Pada Perusahaan $\begin{array}{lllllll}\text { Outsourcing', Jurnal } & \text { Islaminomic, } & \text { Vol. } & \text { 7.No. } & 1 & \text { (2016), } & 34\end{array}$ <https://webcache.googleusercontent.com/search?q=cache:BDsuQOHoCi4J:https://media.neliti.com/media/publicati ons/9138-ID-perlindungan-hukum-terhadap-anak-dari-konten-berbahaya-dalam-media-cetak-danele.pdf $+\& \mathrm{~cd}=3 \& \mathrm{hl}=\mathrm{id} \& \mathrm{ct}=\mathrm{clnk} \& \mathrm{gl}=\mathrm{id}>$.

${ }^{16}$ Caniago, p. 41.
} 
yang diterima seseorang atas pekerjaannya dalam bentuk imbalan materi di dunia (Adil dan Layak) dan dalam bentuk imbalan pahala di akherat (imbalan yang lebih baik). ${ }^{17}$

Berdasarkan uraian diatas sehingga dapat terlihat adanya perbedaab anatar konsep upah konvensional (barat) dan konsep upah syariat (Islam). Dimana perbedaan tersebut adalah, Pertama, Islam melihat Upah sangat besar kaitannya dengan konsep Moral, sementara Barat tidak. Kedua, Upah dalam Islam tidak hanya sebatas materi (kebendaan atau keduniaan) tetapi menembus batas kehidupan, yakni berdimensi akherat yang disebut dengan Pahala, sementara Barat tidak.

\section{Syarat Umum Islam dalam Penentuan Pembayaran Upah}

Sistem upah Islam menghendaki agar pekerja mendapatkan upah yang layak tanpa melanggar hak pengusaha yang sah, dan sebaliknya pengusaha tidak diperbolehkan berlaku sewenang- wenang menghilangkan bagian hak pekerja yang sah. Oleh karena itu upah yang diberikan adalah upah adil dan layak, upah yang berada pada batasan para pekerja mampu memenuhi kebutuhan hidupnya (baik kebutuhan sandang, pangan dan papan yang baik), juga pekerja harus berada pada posisi yang memungkinkan untuk memberikan pendidikan yang baik bagi anak-anaknya dan memperoleh fasilitas medis bagi keluarganya. ${ }^{18}$

Dengan demikian upah yang diberikan kepada pekerja harus berada di antara tingkat upah minimum dan maksimum yang mengacu pada tarap hidup yang lazim serta kontribusi yang telah diberikan oleh para pekerja. Ini sejalan dengan pendapat Ibnu Taimiyah bahwa seorang majikan memiliki kewajiban untuk membayar upah yang adil atau layak kepada pekerjanya. Terkadang majikan mungkin mengambil keuntungan dari pekerja dengan membayar rendah karena tuntutan untuk mendapat penghasilan lebih. Islam menentang sikap tersebut sebab tingkat upah yang terlalu rendah akan berakibat tidak termotivasinya para pekerja untuk berusaha secara maksimal, dan sama halnya jika tingkat upah terlalu tinggi maka para pengusaha mungkin tidak mendapatkan keuntungan dan tidak dapat menjalankan perusahaannya. ${ }^{19}$

Nilai-nilai yang dibawah Islam menghendaki majikan memperlakukan pekerja seperti keluarganya sendiri, sehingga menuntut agar memperlakukan pekerja secara terhormat, manusiawi, kasih sayang, kesejahteraan serta keterjaminan pendidikan dan kesehatan bagi keluarga. Dalam satu hadiś ditegaskan bahwa kebutuhan tempat tinggal merupakan kebutuhan asasi bagi karyawan menjadi tanggung jawab pengusaha, dan bahkan untuk mencarikan jodoh bagi karyawan yang masih lajang. ${ }^{20}$

Dari Al-Mustauridi ibni Saddād, ia berkata: Saya mendengar Nabi SAW. Bersabda "Barangsiapa yang menjadi pekerja bagi kita, maka hendaklah mencarikan istri untuknya; bila ia tidak memiliki seorang pembantu, maka hendaklah mencarikan pembantu untuknya; dan bila ia tidak mempunyai tempat tinggal, maka hendaklah mencarikan tempat tinggal

\footnotetext{
${ }^{17}$ Nur Azizah, 'Studi Komparatif Tentang Outsourcing Pemborongan Kerja Dalam UU Nomor 13 Tahun 2003 Tentang Ketenagakerjaan Dan Syirkah Dalam Islam', MAQASID, 2018, 23.

${ }^{18}$ Rini Sulistiawati, 'Pengaruh Upah Minimum Terhadap Penyerapan Tenaga Kerja Dan Kesejahteraan Masyarakat Di Provinsi Di Indonesia', Jurnal Eksos, Vol. 8.No. 3 (2012), 211.

${ }^{19}$ DILMITA, 'KONSEP UPAH MENURUT IBNU TAIMIYAH (STUDI BURUH TANI DI DESA UJUNG PULAU KECAMATAN TANJUNG SAKTI KABUPATEN LAHAT' (INSTITUT AGAMA ISLAM NEGERI (IAIN) BENGKULU, 2021).

20 S Kalimah, 'Pandangan Ulama Empat Mazhab Dalam Memutuskan Upah Amil Zakat Guna Meningkatkan Optimalisasi Keprofesionalan Amil Zakat', Salimiya: Jurnal Studi Ilmu Keagamaan Islam, Vol. 1.No. 1 (2020), 34 .
} 
JCI

Jurnal Cakrawala Ilmiah

Vol.1, No.3, November 2021

untuk dia".

Secara ideal upah riil dalam masyarakat muslim dengan standar minimal, yakni memungkinkan para pekerja untuk dapat memenuhi semua kebutuhan pokok hidup dan para anggota keluarganya dengan manusiawi. Dikarenakan melihat pengertian upah di atas, yaitu sebagai kompensasi dari manfaat kerja. Upah yang adil dan layak bukanlah suatu konsesi tetapi merupakan hak asasi yang dapat dipaksakan oleh seluruh kekuasaan negara. Pada akhirnya harus disadari oleh masing- masing manusia bahwa dalam mengarungi kehidupan didunia ini saling membutuhkan. Sebuah sikap terpuji jika pengusaha menambah upah sebagai hadiah atau penghargaan apabila pekerja melaksanakan tugasnya dengan tekun dan baik. ${ }^{21}$ Ini dilakukan karena mengikuti petunjuk Allah SWT:

"Sedangkan mereka yang beriman kepada Allah dan menjalankan amal yang sholeh Allah akan menyempurnahkan pahala mereka bahkan akan ditambah melalui karunia_Nya".

Islam tidak memberikan batasan tertentu tentang upah kerja dan itu berarti bahwa masalah ini tidak menjadi fokus pembahasan, sebab keputusan tentang upah menjadi kesepakatan oleh setiap pihak yang terlibat (pengusaha dan pekerja) dan barangkali negara. Islam menekankan nilai-nilai etis berupa keadilan ('adl), kebaikan (ihsān), dan rasa kasih sayang (rahmān) dalam semua hubungan kemanusiaan. (Al-Faruqi: 97).

Upah yang layak adalah upah yang seharusnya dapat mencukupi atau memenuhi komponen kebutuhan hidup layak seperti pakaian, pangan, perumahan, kesehatan, tranfortasi, rekreasi dan tabungan. Komponen tersebut harus ada agar hidup karyawan/staf, guru, dan dosen di setiap instansi dapat dikatagorikan hidup layak. Adapun besarnya nominal upah, honor atau gaji menurut hukum ekonomi Islam, secara umum mempunyai dua dimensi, yaitu dimensi dunia dan akhirat, yang menyangkut moral atau etika seorang manusia muslim sejati. Dalam ekonomi Islam pengupahan, penggajian atau apapun namanya harus bersumber pada Al-qur'an dan Al-hadist dan diperkuat atau dipertegas dengan pendapat para ulama Mazdhab fiqh sebagai rujukan utama sistem pengupahan atau penggajihan. ${ }^{22}$

Dalam ekonomi Islam upah, gaji, honor yang layak harus dapat memenuhi kebutuhan hidup yang layak, dalam pengertian mencukupi kebutuhan sandang, pangan, dan papan yang tidak jauh dari pasaran. Kelayakan upah atau gaji bukan saja dilihat dari besarnya nominal, akan tetapi ada hal yang lebih penting seperti ketepatan waktu dalam membayar upah atau gaji, karena dengan ketepatan waktu pembayaran dapat memenuhi kebutuhan yang sedang mendesak dan melakukan perencanaan. Syarat upah (ujrah) Syarat ujrah adalah sebagai berikut: ${ }^{23}$

1. Upah harus dilakukan dengan cara-cara musyawarah dan konsultasi terbuka, sehingga dapat terwujudkan di dalam diri setiap individu pelaku ekonomi, rasa kewajiban moral yang tinggi dan dedikasi yang loyal terhadap kepentingan umum.

2. Upah harus berupa mal mutaqawwim dan upah tersebut harus dinyatakan secara jelas konkrit atau dengan menyebutkan kriteria-kriteria. Karena upah merupakan pembayaran atas nilai manfaat, nilai tersebut disyaratkan harus diketahui dengan jelas.

${ }^{21}$ CHAPRA and The, p. 254.

${ }^{22}$ Enceng Iip Syaripudin, 'Upah Yang Ditangguhkan Dalam Konsep Ekonomi Islam', Jurnal Naratas, Vol. 1.No. 1 (2018), 14.

${ }^{23}$ Caniago, pp. 44-43. 
Mempekerjakan orang dengan upah makan, merupakan contoh upah yang tidak jelas karena mengandung unsur jihalah (ketidakpastian). Ijarah seperti ini menurut jumhur fuqaha", selain malikiyah tidak sah. Fuqaha malikiyah menetapkan keabsahan ijarah tersebut sepanjang ukuran upah yang dimaksudkan dan dapat diketahui berdasarkan adat kebiasaan.

3. Upah harus berbeda dengan jenis obyeknya. Mengupah suatu pekerjaan dengan pekerjaan yang serupa, merupakan contoh yang tidak memenuhi persyaratan ini. Karena itu hukumnya tidak sah, karena dapat mengantarkan pada praktek riba. Contohnya: memperkerjakan kuli untuk membangun rumah dan upahnya berupa bahan bangunan atau rumah.

4. Upah perjanjian persewaan hendaknya tidak berupa manfaat dari jenis sesuatu yang dijadikan perjanjian. Dan tidak sah membantu seseorang dengan upah membantu orang lain. Masalah tersebut tidak sah karena persamaan jenis manfaat. Maka masing-masing itu berkewajiban mengeluarkan upah atau ongkos sepantasnya setelah menggunakan tenaga seseorang tersebut.

5. Berupa harta tetap yang dapat diketahui. Jika manfaat itu tidak jelas dan menyebabkan perselisihan, maka akadnya tidak sah karena ketidak jelasan menghalangi penyerahan dan penerimaan sehingga tidak tercapai maksud akad tersebut. Kejelasan objek akad (manfaat) terwujud dengan penjelasan, tempat manfaat, masa waktu, dan penjelasan, objek kerja dalam penyewaan para pekerja.

Dari pejelasan di atas maka syarat umum Islam dalam penentuan pembayaran upah sebagai berikut:

a. Upah harus ditentukan sebelum pekerjaan dimulai

b. Upah dibayar secara layak

1. Cukup pangan, sandang dan papan

2. Sesuai dengan pasaran

c. Upah diberikan secara adil

1. Jelas dan transparan

2. Proporsional

d. Upah harus diberikan tepat waktu sesui akad

\section{PENUTUP \\ Kesimpulan}

Berdasarka pembahasan di atas maka dapat disimpulkan perbeadan dasar antara konsep upah dalam Islam dan Barat. Menurut Islam uapah adalah imbalan yang diterima seseorang atas pekerjaannya dalam benruk imbalan materi di dunia yaitu (adil dan layak) dalam bentuk imbalan pahala di akhirat (imbalan yang lebih baik). Islam melihat upah sangat besar kaitannya dengan konsep moral. Upah dalam Islam tidak hanya materi (kebenadaan atau keduniaan) tetapi menembus batas kehidupan, yakni berdimensi akherat yang disebut dengan pahala.

Sedangkan Barat menganggap bahwa upah atau gaji biasa, pokok atau minimum yang dibayarka secara langsung baik dalam bentuk uang tunai atau barang, oleh pengusaha kepada pekerja dalam kaitan dengan hubungan kerja. Barat memandang upah hanya sebatas materi yang di berikan tampak memasukkan dimensi moral didalamnya dan idak memiliki dimensi akherat. 
JCI

Jurnal Cakrawala Ilmiah

Vol.1, No.3, November 2021

\section{DAFTAR PUSTAKA}

[1] Azizah, Nur, 'Studi Komparatif Tentang Outsourcing Pemborongan Kerja Dalam UU Nomor 13 Tahun 2003 Tentang Ketenagakerjaan Dan Syirkah Dalam Islam', MAQASID, 2018, 23

[2] Caniago, Fauzi, 'Ketentuan Pembayaran Upah Dalam Islam', Jurnal Textura, Vol. 1 (2018), 48

[3] CHAPRA, M. UMER, and The, Islam and The Economic Challenge (Kano. Nigeria British: The Islamic Foundation and The International Institute of Islamic Thought, 1992)

[4] DILMITA, 'KONSEP UPAH MENURUT IBNU TAIMIYAH (STUDI BURUH TANI DI DESA UJUNG PULAU KECAMATAN TANJUNG SAKTI KABUPATEN LAHAT' (INSTITUT AGAMA ISLAM NEGERI (IAIN) BENGKULU, 2021)

[5] Ghofur, Ruslan Abdul, 'Konsep Upah Dalam Ekonomi Islam' (Arjasa Pratama, 2020)

[6] Hendy Herijanto Muhammad Nurul Hafiz, 'Pengupahan Perspektif Ekonomi Islam Pada Perusahaan Outsourcing', Jurnal Islaminomic, Vol. 7 (2016), 34 <https://webcache.googleusercontent.com/search?q=cache:BDsuQOHoCi4J:https:// media.neliti.com/media/publications/9138-ID-perlindungan-hukum-terhadap-anakdari-konten-berbahaya-dalam-media-cetak-danele.pdf $+\& \mathrm{~cd}=3 \& \mathrm{hl}=\mathrm{id} \& \mathrm{ct}=\mathrm{clnk} \& \mathrm{gl}=\mathrm{id}>$

[7] Kalimah, S, 'Pandangan Ulama Empat Mazhab Dalam Memutuskan Upah Amil Zakat Guna Meningkatkan Optimalisasi Keprofesionalan Amil Zakat', Salimiya: Jurnal Studi Ilmu Keagamaan Islam, Vol. 1 (2020), 34

[8] Kusumastuti, Annisa Silvi, 'Menurut Ibnu Miskawaih', 07 (2020), 250-72

[9] M. Yazid Affandi, Fiqih Muamalah Dam Implementasinya Dalam Lembaga Keuangan Syari'ah (Yogyakarata: Logung Pustaka, 2012)

[10] Nurmala Sari, Safwan Kamal, Junaidi, Mastura, 'KELAYAKAN DAN KEADILAN DALAM PENETAPAN UPAH NELAYAN KAPAL PUKAT LANGGAR KUALA LANGSA DITINJAU DARI PERSPEKTIF ETIKA BISNIS ISLAM', J-EBIS (Jurnal Ekonomi Dan Bisnis Islam), Vol. 6 (2021), 54 <https://doi.org/10.32505/j-ebis.v6i1.2624>

[11] Prof. Dr. H Boedi Abdullah, M.Ag, and M.Si Drs. Beni Ahmad Saebani, Metode Penelitian Ekonomi Islam Muamalah (CV Pustaka Setia, 2014)

[12] Salamah, Baitus, and Imahda Khoiri Furqon, 'Pengaruh Pandemi Covid Terhadap Penerimaan Pajak Di Negara Indonesia Pada Tahun 2020', Jurnal Akuntansi, Perpajakan Dan Auditing, 1 (2020)

[13] Sayyid Sabiq, Fikih Sunnah 13 (Bandung: PT Alma'arif, 1987)

[14] Sulistiawati, Rini, 'Pengaruh Upah Minimum Terhadap Penyerapan Tenaga Kerja Dan Kesejahteraan Masyarakat Di Provinsi Di Indonesia', Jurnal Eksos, Vol. 8 (2012), 211

[15] Syaripudin, Enceng Iip, 'Upah Yang Ditangguhkan Dalam Konsep Ekonomi Islam', Jurnal Naratas, Vol. 1 (2018), 14

[16] Wahbah al-Zuhayli, Al-Fiqh Al-Islam Iy Wa Adillatuhu, Juz IV

[17] Waliam, Armansyah, 'Upah Berkeadilan Ditinjau Dari Perspektif Islam', Jurnal STIE Bank BPD Jateng, Vol. 5 (2017), 292

[18] Wiwin Agustian, Dina Mellita, 'KONSEP PENGUPAHAN DALAM MANAJEMEN $\begin{array}{lllll}\text { SYARIAH', } & \text { JIBM, } & \text { Vol. } & 3 & (2020),\end{array}$ <https://journal.binadarma.ac.id/index.php/BINAMANAJEMEN/article/view/827/46 
Jurnal Cakrawala Ilmiah

Vol.1, No.3, November 2021

$9>$ [accessed 7 October 2021]

[19] Yulianti, Yulianti, Salmaini Yelly, and Khotimah, 'MENJADI WANITA KARIR Persepsi Karyawan Muslin Dan Kristen Di Pekanbaru', TOLERANSI: Media Ilmiah Komunikasi Umat Beragama, Vol, 12 (2021), 175 <https://doi.org/10.24014/trs.v12i2.13546> 
HALAMAN INI SENGAJA DIKOSONGKAN 